\title{
Children's Moral Development in Marginalized Communities
}

\author{
Ayu Rissa Atika, Rukiyati \\ Yogyakarta State Unversity, Yogyakarta, Indonesia \\ e-mail: ayu.rissa2016@student.uny.ac.id
}

\begin{abstract}
Marginal vulnerable and exploitative is a term for marginalized because they do unclear jobs, careers, and also no hope whatsoever in the future. Vulnerable because of the risks that must be covered from time to time, in terms of health and social. Including exploitative because they usually have bargaining position is very weak, subordinated, and fishing into arbitrary objects of the family, the act of thugs or irresponsible officials irresponsible. The marginal people in Kampung Srirahayu work as scavengers, street singers, and prostitutes. This study aimed to describe the developing moral and development of moral early childhood children in marginal people of Kampung Srirahayu. The approach used in this research is a qualitative case study. This study involved parents, early childhood, TPA educators. The design used in this research a case study and used triangulation technique of validity and source. The results of this study indicated that the moral development of early childhood on marginal people in Kampung Srirahayu covered aspects of materials, educators, methods, and evaluation. Factors that encouraged moral development included: (a) the existence of Taman Pendidikan Alqur'an (TPA), (b) early childhood in Kampung Srirahayu following TPA activity, and (c) restriction from parents to children not to interact with children who dropped out.
\end{abstract}

Keywords: moral development, marginalized

\section{INTRODUCTION}

Early Childhood is an individual figure who is undergoing the development process with the rapid and fundamental for the next life. Early Childhood is in the age range of $0-8$ years. At this time the process of growth and development in various aspects are experiencing a rapid period in the development of human life. The child born into the world is a holy being. The child is like a sponge that will soon absorb all kinds of water that exists. At this stage, the child does not have a filter of good or bad. Parents should understand the characteristics of the child must be good at giving a filter for children. Children have potential mental, spiritual, and moral development to build.

In this case, the family is a very decisive factor in the future of child development. From the family side, the development of education has started since still in the womb. So the family knows a lot of child development at the time still in the womb until he was an adult. One is the moral development that describes the change in the individual's understanding of feelings and moral principles during life. Morality covers many dimensions, the most prominent being emotion, knowledge and reasoning, values and morals are relevant. Moral values become a mandatory order for all parents who will be imitated by children to be a moral guide in life in the future. A person is said to be moral if the person's behavior is in accordance with the values and morals that exist in society around the moral that is upheld by the social group. It should be the obligation of parents to provide care for their children to develop optimally so as to be qualified human beings from all aspects not only parenting Parents are obliged to provide education for their children both formal and informal. Among others, with the planting of moral values that must be implanted in children from an early age, so that children have a good foundation to prepare their lives in the future. 
Moral problems that exist in Kampung Srirahayu Karangklesem Purwokerto is an early childhood moral development because early childhood who is experiencing imitation will imitate the environment and this is a very big influence on the moral development of children. In a family, there will be a process of culture from parents to children. Starting from the introduction of family members, fellow members in the community environment followed by the fostering of moral values prevailing in the community. Moral values in the environment especially the family is the main source that will shape the personality of a child in the future. This aspect becomes the guidance or obligation of parents who will be an example for the child so that they always maintain good deeds to others.

Most townspeople have low levels of education and drop out of school, so their knowledge of moral education early childhood are lacking. This is supported by the parent's way of bringing their children on a negative profession that they have such as street singer and begging. Moreover, commercial sex workers also double as beggars. Limited time and knowledge to the education of children in the family is still very limited. Each person's moral development is not always the same according to his age, but the experience of someone interacting with the crowd will affect the level of moral development that is owned by the child.

Researchers conduct pre-research in Kampung Srirahayu with the provision of such information. The pre-research conducted, 5 informants who have a profession as a street singer and 1 "psk" said that they do so because of economic factors. However, their hopes are great for their children even though they are a marginalized society. They hope the lives of their children will be much better than their lives. Based on the research, the researcher is interested to conduct research the moral development of early childhood in Marginal people in Kampung Srrahayu Karangklesem Purwokerto.

\section{LITERATURE REVIEW}

\subsection{Moral Development}

Jamie (2003) Morals are good and bad teachings about deeds and behavior (akhlak). the moral sense in a more comprehensive formulation is formal Moral as a set of ideas about behavior with a certain basic color that is held by a group of humans in a particular environment, Moral is a teaching about the behavior of life-based on a particular view of life or religion, Moral as behavior human life based on the realization that it is bound by the necessity to achieve good, in accordance with the values and norms prevailing in its environment (Jamie 2003). moral is a willingness to accept and enforce rules of values or moral principles, such as the call to do good to maintain the rights of others, to maintain order and security, forbidding adultery, killing and drinking, one can be said to be moral when he behaves in accordance with values upheld by social groups or community groups (Yusuf Syamsu 2008).

The moral is a habit that is formed from social standards that are also influenced from outside the individual. It is a movement from outside of his selfpower to the depths of himself and consistent and remains within himself (Hurlock 2004). While moral education is an educational program (school and out of school) that organizes and simplifies the moral source presented with regard to psychological considerations for educational purposes (Zuriah 2007). Moral education is divided into three kinds of specifications of moral education in the household, moral education in schools, moral education in society (Zakiyah 1976). The moral competence and religious values of the child are again exposed in detail in some indicators of the age of the child 1 to the year is to say short prayers, to love and care for God's creation, to begin to mimic the prayer movements of adults, to pray before and after activities , carrying out religious worship, loving and nurturing God's creation, loving the homeland, knowing deliberation and consensus, love among fellow ethnic Indonesians, knowing politely with gratitude, blessing when meeting with others, practicing to always order and obey the rules, keep environmental health, responsible for the tasks assigned, neat in acting and dealing and working, maintaining environmental cleanliness, courtesy, responsible for the tasks assigned Agus, setiawati Farida 2006). The scope of moral education includes materials, educators, methods, and evaluation (Zuriah 2007).

Moral development has an intrapersonal dimension, which regulates one's activities when he is not engaged in social interactions and interpersonal dimensions that govern social interaction and conflict resolution (Santrock 2007). The stage of moral development consists of two stages, namely the stage of heteronomy (heteronomous morality) and the Autonomous stage 
(autonomous morality). At the heteronomy stage, children tend to accept just the rules given, this stage occurs in children aged 4-7 years.

This stage of development children considers justice and rules as the nature of the world that cannot change and out of human control. This stage of the child believes that laws and regulations make people. But in the second stage of the child who has the moral sense already realized that in rate an action one must consider the intent of the perpetrator and the consequences. The second stage is autonomous morality, at this stage occurs in children aged 7-10 years. The stage of the child's autonomous morality in transition shows some features of the first stage of the development of autonomous morality. At the stage of autonomous morality is closely related to the operational and operational pre-operational capabilities. At this stage, the child still thinks subjectively and the process of thinking is still concrete. Meanwhile, the preoperative children begin to develop objective thinking, the preoperative stage of the child is still centered egocentric. Children decentralize their views and accept the world from the other person's perspective. While at the age of 11 years children see morality more flexible, and social-oriented (Santrock 2007).

The ultimate goal of moral education is to develop an awareness of right and wrong. Barriers that often occur in family care. The family has a very important role in the development of children, especially moral. So far family perception in child development is only limited from the biological relationship. Establishment of moral values in children can be done three ways through training activities, conducting activities play, doing learning activities (Mardiya 2009). The types of problems in moral education are individual and social issues, issues of moral principles, reasoning, and ethics, content issues, behavior problems and behavior (Ceppy 1988).

\subsection{Marginalized people}

Marginalization is a phenomenon of imbalance in the acquisition of opportunities in economic, social and educational aspects by a group of societies (Alcock 1993). Permensos 2012 about Persons with Social Welfare Problems (PMKS) are individuals, families, groups and/or communities who, due to a hindrance, difficulty or disruption, are unable to perform their social functions, so that they cannot fulfill their physical, physical, or social needs adequately and reasonable. Marginal vulnerable and exploitative is the term-term to describe the condition and life of street children. Marginal because they do a job that is not a clear career ladder, less appreciated, and generally also does not promise any prospect in the future. Vulnerable because of the risk that must be borne due to long working hours, both in terms of health and social. The so-called exploitative because they usually have bargaining position that is very weak, subordinated, and tends to be the object of arbitrary treatment of the family, the act of thugs or irresponsible officers (Suyanto 2010). Marginal community groups include entrepreneurs without capital and no government facilities now called the very weak economic class (Soedjatmoko 1981). The marginalized community becomes eight groups: street vendors, beggars, street singers, street vendors, street children, disabled communities, transgender or transgender communities, and minority religious groups (Aziz 2005).

\section{METHOD}

Participant in this study is 6 parents, 6 children of early age, educator TPA, village device (rt) which is a marginal people in Kampung Sri Rahayu Karangklesem Purwokerto.

This research uses a qualitative approach. The type of research used is a case study. Qualitative research as a human instrument serves to define the focus of research, selecting informants as data sources, collecting data, assessing data quality, analyzing data, interpreting data and making conclusions on all findings (Sugiyono 2012). The type of data in this study is qualitative in the form of words of interview, observation and supporting documentation. Good data is data taken from appropriate and accurate sources (Arikunto 2006). Sources of data in the form of interviews, observation, and documentation are also observations with informants, in this study used as a primary data source is the observation and interviews conducted by parents and children. Techniques used for the validity of this research data using trianggulation in the testing of credibility is interpreted as checking data from various sources in various ways and various times. Thus there is a triangulation of sources, triangulation of data collection techniques and time of use (Sugiyono 2014). Steps of data analysis after the study was conducted for two months starting with pre-research 
conducted in December 2017, and the implementation of research conducted in January 2018-February 2018.

\section{RESULT AND DISCUSSION}

\subsection{Result}

Early childhood morale development of Kampung Srirahayu Karangklesem Purwokerto is done by parents and educators of TPA internally in family and community environment. The way that is done through daily activities at home and the environment. In the following explanation, the way parents develop early childhood morale and cover the scope of materials, educators, methods, and evaluation. The material of moral development involves saying the daily prayer, caring for and nurturing God's creation, starting to imitate the prayer movements of adults, praying before and after starting activities, performing religious services, knowing good manners and gratitude, giving greetings when meeting other people. The educator of moral development of early childhood of marginal society in Srirahayu village is parents who still have low education and not infrequently among those who drop out of school, from 6 informants only 1 parent with high school education. Overall, parents as informants in Kampung Srirahayu Karangklesem Purwokerto still cannot be a moral example in terms of education and appearance. Then the TPA educator is a teenager of Srirahayu village who is still in high school education, is a friendly figure with children, very friends with children. Clothes TPA Educator Clothes cover the nakedness and can be an example for children. They use the modeling method in developing the moral of the child's religion.

From these statements, TPA teachers can already be role models or examples for children in developing their morale. The method used by parents to discipline their children to follow the prayers in mushola, to read prayers before and after meals are also prayer before and wake up from sleep. The exemplary method is a method conducted by educators TPA Kampung Srirahayu Karangklesem Purwokerto to develop early childhood morale. The exemplary method is a method that can be an example for children. the behavior of a TPA educator will be seen and imitated by the child, so as educators should be able to provide good examples for children, reward and punishment methods used by parents in developing moral by giving praise when they perform congregational prayers according to parent's orders and the punishment by scolding the child is also the parent who punishes him with a pinch if the child does not do what the parent tells them to do. Evaluate the development of daily rote prayer techniques, simple traditions, short letters, and iqra.

The development of morale and religion of early childhood Kampung Srirahayu Karangklesem Purwokerto in accordance with several stages. This can be seen from the observations made by researchers. In accordance with Permendiknas reference No. 137 the Year 2014, according to morals in Kampung Srirahayu only done by educators TPA.

STTPA (Standards of Achievement Level) which is a reference for developing standards of content, process, assessment, educator, educational staff, facilities and infrastructure, management, and financing in management, and implementation of early childhood education. During the observations made during the two months stage of the achievement of moral development of children aged 5-6 years is 1) know the religion adopted, Most of their children are introduced with religious activities among others by inviting prayers in congregation, teach children to fast Ramadan. 2) working on worship, This can be seen when researchers do observations in the mosque. Children are able to perform ablution movements in the correct order even though they are not perfect movement they do. Furthermore, children are able to perform the movement of prayers that they do when congregation. 3) Be honest, helpful, polite, respectful, grateful this is seen when AY greet and kiss his mother's hand when going to a friend's house. Furthermore, during the study, children always pray before and after they eat. Children also have been learned to thank. Sereprti is visible when BY is fed by his neighbors, he pronounces a tacit acceptance to the neighbor who feeds him. Some children of Kampung Srirahayu have understood to behave politely and know thanks to others.4) to maintain personal hygiene and environment, It can also be seen when children do TPA activity in mushola. Children who will conduct TPA activities prepare a small bench for teachers and a whiteboard. After they do the TPA activities until finished, the children are responsible for returning the table and come to sweep the floor of the mosque that they use to conduct the TPA activity in the mosque. e) know 
the religious day, Supported from the observations made that the children of Kampung Srirahayu know the religious holidays (Idul Fitri). 6) The development of respect for other religions in Srirahayu is not so visible. This is because all the children in Kampung Srirahayu embraced Islam.

\subsection{Discussion}

The moral education material developed in Kampung Srirahyu Karangklesem Purwokerto is: pronouncing short prayers, beginning to imitate the prayer/prayer movements performed by adults, praying before and after doing activities, performing religious services, knowing good manners and gratitude, giving greetings when meeting other people. The material includes the child saying a prayer after and before eating, say thank you if you accept something from others, and praying before and after sleep, and say prayers in and out mushola. Children pray in the mosque and able to imitate the prayer movement. Children can be grateful if they receive something from others, and greet and kiss their hands to those older than them.

Kampung Srirahayu Educators are parents and TPA educators. Parents are child-friendly, but their experience and knowledge in religious morals are lacking, and their education is lowly educated as most parents there are only elementary or junior high school graduates. The TPA teacher is the second educator for the moral development of the child's religion in society, they are good and kind to the children but they are still high school students, so it is still learning a process and not yet optimal. The friendly behavior provided by educators in TPA activities is indispensable for children because the child will feel comfortable while receiving the lessons and knowledge provided by the educator.

The method of moral development in the village of Srirahayu Karangklesem Purwokerto needs to be improved. The method used is the method of habituation, exemplary method, and reward and punishment. It is necessary to improve the method of moral development of children in the village of Srirahayu Karangkelsem Purwokerto.

Evaluation of early childhood moral development in Kampung Srirahayu Karangkelsem Purwokerto only through landfill activities namely the system of recitation of a memorandum of prayer, hadith, and iqra. Every day rote deposit tests are done to determine the moral development of children. Actually, communication between parents and educators TPA not so good, because many parents are less concerned about the moral development received by their children through landfill activities. Parents are urgently needed in terms of evaluation by TPA educators because the moral evaluation of religion cannot be seen in the child's behavior while in the TPA alone. Evaluation is done by educators, in this case, TPA educators only include memorization of short letters, daily prays, simple traditions, and iqra. Evaluation is less optimal because many parents do not do evaluation.

The Moral Development of early childhood of marginal kampung of Srirahayu Karangklesem Purwokerto has reached the stage of moral development which is in accordance with the stage of moral development in accordance with Permendiknas reference no 137 of 2014. These findings are quite encouraging, since the village of Srirahayu most of the people are marginal people where they are marginalized people living outside the existing norms, working as street singers, scavengers, psk and lifestyle in their environment such as large dropped out rate, smoking drinking hard for underage children is still reasonable even they do so beside-edge of Kampung Srirahayu.

This can be seen when the observations made by researchers. Stages of achievement of development in the village of Srirahayu in children aged 5-6 years. The level of achievement of the first development is the child knows the religion he embraces. Srirahayu village children are all Muslims. They already know God that they believe is Allah SWT. The second level of achievement is the work of worship, divided into three indicators. Children are able to perform the prayer movement, children are able to perform wudlu movement, children are able to perform religious movements according to their respective religions. At this stage most can already do it. But there are some children who have not been able to perform the movement especially wudlu movement. The second level of achievement is the work of worship, divided into three indicators. Children are able to perform the prayer movement, children are able to perform wudlu movement, children are able to perform religious movements according to their respective religions. At this stage most can already do it. But there are some children who have not been able to perform the movement especially wudlu movement. the attainment of further development is to behave in courtesy, respect, gratitude, seen when the child kisses hands and greet the parents when they are 
about to leave the house in this case to the mosque for praying in congregation. Furthermore, during the research children always say prayers before and after meals done. The fourth achievement is to maintain personal hygiene and environment. The next stage is to know the religious holidays, at this stage the children of Kampung Srirahayu have known the religious day that they believe. All the children in Kampung Srirahayu are Muslim, the children already know about the big day of Islam that is Eid al-Fitr. The development of respect for other people's religion in the village of Srirahayu is not so visible. This is because all the people of Srirahayu village are Moslems. Children in the village of Srirahayu every day interact with parents and people who are Muslims.

\section{CONCLUSION}

Early childhood moral development in Kampung Srirahayu Karangklesem Purwokerto has been implemented in terms of aspects, materials, educators, methods and evaluation. The material developed in the village of Srirahayu Karangklesem Purwokerto includes short prayers, loving and nurturing God's creation, beginning to imitate the prayer / prayer movements performed by adults, praying before and after starting activities, carrying out religious worship, recognizing courtesy by thanking, say hello when meeting with others. Srirahayu village educator Karangklesem Purwokerto there are two namely, parents and educators TPA. TPA educators are a friendly and courteous figure for children. TPA educators have been a good example for children, in terms of polite, well-mannered and polite. Educators have a good personality. Therefore, children feel comfortable with TPA educators. Yet another case with parents, in terms of appearance and language, they still cannot be good role models for children. methods of moral development in early childhood in the village of Srirahayu Karangkelsem Purwokerto according to researchers during the observation using methods of habituation, exemplary, and reward and punishment. Evaluation conducted in the village of Srirahayu
Karangklesem Purwokerto for moral development of children conducted by educational TPA just by means of daily rote prayer, simple traditions, short letters, and iqra.

\section{REFERENCES}

[1] Agus, Setiawati Farida. (2006). Pendidikan moral dan nilai-nilai agama pada anak usia dini: bukan sekedar rutinitas. Jurnal Ilmiah Paradigma, NO. 02. Th 1.IsSN 1907-297X

[2] Alcock, Pete. (1993). Understanding Provety. UK: Macmillan Press Ltd.

[3] Arikunto, S. (2006). Prosedur penelitian suatu pendekatan, praktik. Jakarta: PT Bina Aksara.

[4] Aziz, Moh. Ali, dkk. (2005). Dakwah pemberdayaan Masyarakat: Paradigma Aksi metodologi. Yogyakarta: PT. LKiS Pelangi Nusantara.

[5] Ceppy, HC. (1988). Pendiidkan moral dalam beberapa pendekatan. Jakarta: Diknas

[6] Elizabeth B. Hurlock. (2004). Psikologi Perkembangan. Jakarta : PT Gelora Aksara Pratama.

[7] John W. Santrock (2007). Perkembangan Anak, ed tujuh, jilid kedua. Erlangga: Jakarta.

[8] John W. Santrock. (2010) Child development, (11th). Americas: MCGraw Hill.

[9] Kirkley, Jamie. (2003). Principles For Teaching Problem Solving. Plato Learning, Inc.

[10] Mulyasa, (2013). Pengembangan dan Implementasi Kurikulum 2013. Bandung: Remaja Rosdakarya.

[11] Permensos. (2012). Pedoman Pendataan dan Pengelolaan Data Penyandang

[12] Masalah Kesejahteraan Sosial dan Potensi dan Sumber Kesejahteraan Sosial. Tanpa nama kota: Tanpa penerbit

[13] Soedjatmoko. (1981). Dimensi Manusia Dalam Pembangunan. Jakarta: LP3ES.

[14] Sugiyono. (2012). Pengembangan karakter anak melalui kontervasu moral sejak dini. Indonesia Joural Of Conservation, Vol. 1, No. 1, hal. 4048.

[15] Sugiyono. (2014). Metode penelitian kuantitatif, kualitatif dan r\&d. Bandung: Alfabeta.

[16] Yusuf, Syamsu. (2008). Psikologi Perkembangan Anak. Bandung: Remaja Rosdakarya.

[17] Zuriah, Nurul. (2007). Pendidikan moral dan budi pekerti: dalam perspektif perubahan. Jakarta: Bumi 